\title{
Comparative Analysis Of Mechanical Properties Of Rubber-Kenaf-Wire-Cotton Lamination On Epoxy- Carbon-Ramie Composite
}

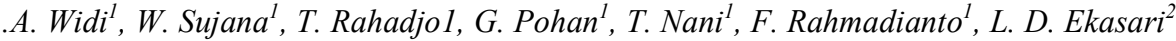 \\ ${ }^{I}$ Department of Mechanical Engineering, National Institute of Technology of Malang, Malang, Indonesia \\ ${ }^{2}$ Accunting Department, university of Tribhuwana Tunggadewi, Malang, Indonesia \\ Email:aswidi@yahoo.com
}

\begin{abstract}
The use of fiber has been widely researched but the use of several fibers as reinforcement does not necessarily result in optimal mechanical properties. This study aimed to determine the tensile strength and impact strength of composite materials using an epoxy matrix with the addition of rubber variations to increase the ductility of the matrix. Meanwhile, the fibers used for reinforcement are carbon fiber and ramie. In this study, the reinforcement added a variety of kenaf fiber, wire and cotton. This was to compare the role of kenaf fiber, wire and cotton in improving the mechanical properties of composite materials. The percentage of rubber volume fraction added to the epoxy is $30 \%, 40 \%$ and $50 \%$. The highest tensile test results were shown in the $30 \%$ epoxy rubber-carbon fiber-ramie fiber-kenaf specimen which was $10.67 \mathrm{Kgf} / \mathrm{mm} 2$, and the lowest result was the epoxy 50\% rubber-carbon fiber-ramie-wire specimen, which was 5.752 $\mathrm{kgf} / \mathrm{mm} 2$. The fracture analysis of the tensile test showed that the fracture area is formed by debonding phenomena between fibers and matrices. The highest impact strength was found in the $50 \%$ epoxy rubber-carbon fiber-ramie-wire specimen, which was $0.039 \mathrm{kgf} / \mathrm{mm} 2$. Meanwhile, the lowest impact strength was found in the $40 \%$ epoxy rubber-arbon fiber-ramie fiber-cotton specimen, which was $0.030 \mathrm{kgf} / \mathrm{mm}^{2}$. In general, the trend of impact test data shows that as the percentage volume fraction of rubber increases, the impact strength of the composite material increases. Based on the test analysis, it was concluded that increasing the percentage of rubber will increase the impact strength of the woven wire reinforcement. However, the impact strength is inversely proportional to kenaf fiber reinforcement, where the addition of the percentage of rubber will reduce the impact strength. This showed that the mechanical properties were not always influenced by the percentage of rubber but were very dependent on the type of fiber. This was also shown in the results of the tensile strength test. In general, it was known that the adhesion between fiber and matrix laminates affected the mechanical properties in addition to the strength of the reinforcement.
\end{abstract}

Keywords epoxy, rubber, mechanical properties, woven wire, kenaf, cotton

Paper type Research paper

\section{INTRODUCTION}

Composite is an engineering material which is a combination of two or more different materials and each of which has the properties and characteristics of the constituent materials. This is done to obtain a special characteristic of the combined material, but the natural or inherent properties of the constituent materials are still there and when broken down, the composite constituent materials can still be seen with the naked eye [4].

Composite consists of a matrix and reinforcement. The matrix can be polymers, ceramics or metals, and the reinforcement can be either natural or synthetic fibers. The use of composite materials can be designed and tailored to the desired needs. Polymer is a material that is often used as a matrix in composite materials.

Nowadays, the use and utilization of composite materials are growing, along with the increasing use of these materials which are increasingly widespread, ranging from household appliances to the small-scale industrial sector and large-scale industry [5]. During its development, the fibers used are not only synthetic fibers but also natural fibers. Natural fiber composites have other advantages compared to glass fibers, natural fiber composites are now more widely used because they are large in number and are environmentally friendly and can be degraded naturally and the price is cheaper than glass fiber [11].

Given that polymer resin will harden when dry, the resulting product will feel very stiff and brittle when the composite product has a rather thick layer. Therefore, the additional material is needed in the composite to get a composite product that is hard, strong, light, but somewhat flexible.

Rubber is a polymer material that has flexible properties that can be obtained from natural or synthetic. The rubber material itself has been widely applied in various fields such as transportation where rubber is used as a vehicle wheel which is reinforced with fiber so that the resulting vehicle wheels have strong properties but remain flexible. I Wayan Sujana and I Komang Astana Widi [12] have conducted research by mixing epoxy resin with silicone rubber as a matrix in a composite material with variations in the addition of silicone rubber as much as $10 \%, 20 \%$ and $30 \%$. In the tensile test 
and impact test, the results showed that in the tensile test, "Tensile strength of the composite decreases as the volume fraction of white rubber in the matrix increases, while the strain increases". Moreover in the impact test "The more the volume fraction of white rubber is added, the impact strength of the composite increases". In this study, the authors had no prior knowledge whether the additive of silicone rubber above $30 \%$ to epoxy has increased or decreased, so further study is needed.

In line with the explanation above, the authors want to conduct a research on composite materials about the addition of a mixture of silicone rubber to epoxy with the percentage of rubber addition of $30 \%, 40 \%$ and $50 \%$ as reinforcement in laminated composites, to prove the use of an epoxy-rubber mixture as reinforcement in laminated composite materials in tensile testing and impact testing have increased or decreased strength.

Polymer matrix composites and carbon matrix composites (commonly referred to as carbon-carbon composites). Carbon matrix composites are actually formed from polymer matrix composites through the inclusion of an extra step of the combination and densification of the original polymer matrix. The second group refers to the form of reinforcement, for example powder reinforcement, whisker reinforcement, elongated fibers and woven composites [6].

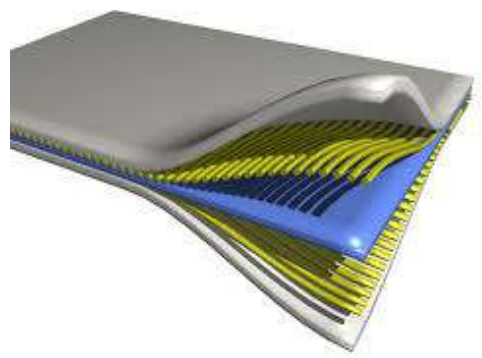

Fig. 1. An example of a layer in a composite

The composite material consists of two elements, namely fiber and a fiber binding material called a matrix (Epoxy). Fiber is one of the constituent elements of composite materials, which is fiber, which mainly determines the characteristics of the composite material, such as stiffness, and other mechanical properties. These fibers hold most of the forces acting on the composite material. There are two types of fiber, namely natural fibers and synthetic fibers. The main natural fibers are cotton, wool, silk and ramie. Meanwhile, synthetic fibers are rayon, polyester, acrylic, and nylon. There are many other fibers made for various purposes, while the ones mentioned above are the most widely known types. Broadly speaking, it can be said that natural fibers are a group of fibers produced from plants, animals and minerals. The use of natural fibers in the textile and paper industry is widely available in the form of silk, cotton, cotton, ramie, ramie, jute, fine ramie and leaf fibers. Epoxy is a liquid resin that contains several epoxide groups such as diglycidyl ether of bisphenol A (DGEBA) which has two epoxide groups. The curing process is carried out by adding a curring agent, for example diethylene triamine (DELTA). During the curing process the DGEBA molecules will form cross-link bonds. These bonds will produce a three-dimensional shape called a network and eventually form a solid epoxy. Epoxy is a thermoset polymer which is a multipurpose material that is widely used in everyday life. Epoxy is widely used in the aviation industry and for sports equipment [5].

\section{METHOD}

In this study, rubber was used as composite reinforcing material with variations of $30 \%, 40 \%$, and $50 \%$. Composite matrix was epoxy resin. Apart from these two materials, the composite specimens had other additional materials, namely carbon fiber, ramie fiber, kenaf fiber with thicknesses of 3, 2, and $2 \mathrm{~mm}$, respectively. Composite specimens were prepared in accordance with ASTM D 638 type III (tensile test specimen) and ASTM D 256 (impact test specimen) standards. Each variation of the specimen received three tests, both tensile and impact tests to obtain the average value.

\section{Research tools and materials}

The equipment used in making specimens included drilling machines, grinding machines, coarse saws, fine saws, combination ring wrenches, scissors, triangle files, mold presses, brushes, measuring cups, sandpaper, spets, gloves, cloth wipes, glasses mixer, spoon, digital gram scale, caliper, steel ruler. The materials used were epoxy resin, silicone rubber RTV 888, Kevlar carbon fiber, ramie fiber, SS304 woven wire, cotton fiber and kenaf fiber.

\section{Specimen Preparation}

Specimens were prepared according to ASTM standards, namely for tensile test specimens (ASTMD 638 Type III) and impact tests (ASTMD 256) 
The manufacture of reinforcement for the epoxy-rubber mixture (Fig. 2)

- A mixture of 70\% epoxy and 30\% rubber. (140 grams of epoxy and 60 grams of silicon rubber).

- A mixture of $60 \%$ epoxy and 40\% rubber. (120 grams of epoxy and 80 grams of silicon rubber).

- A mixture of 50\% epoxy and 50\% rubber. (100 grams of epoxy and 100 grams of silicon rubber).

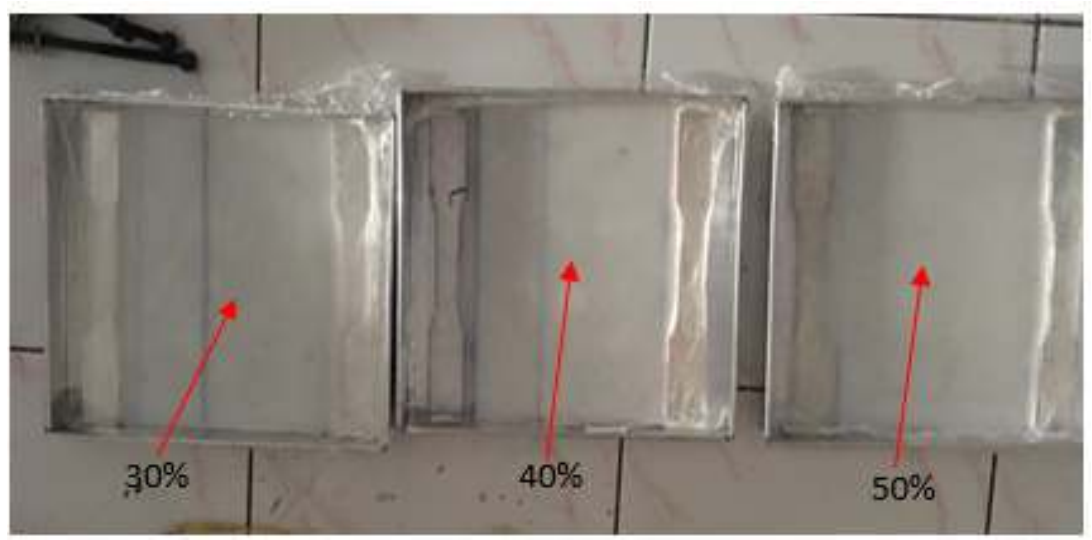

Fig. 2. Epoxy-rubber Mixture Reinforcement Plate

Placement of the reinforcing layer

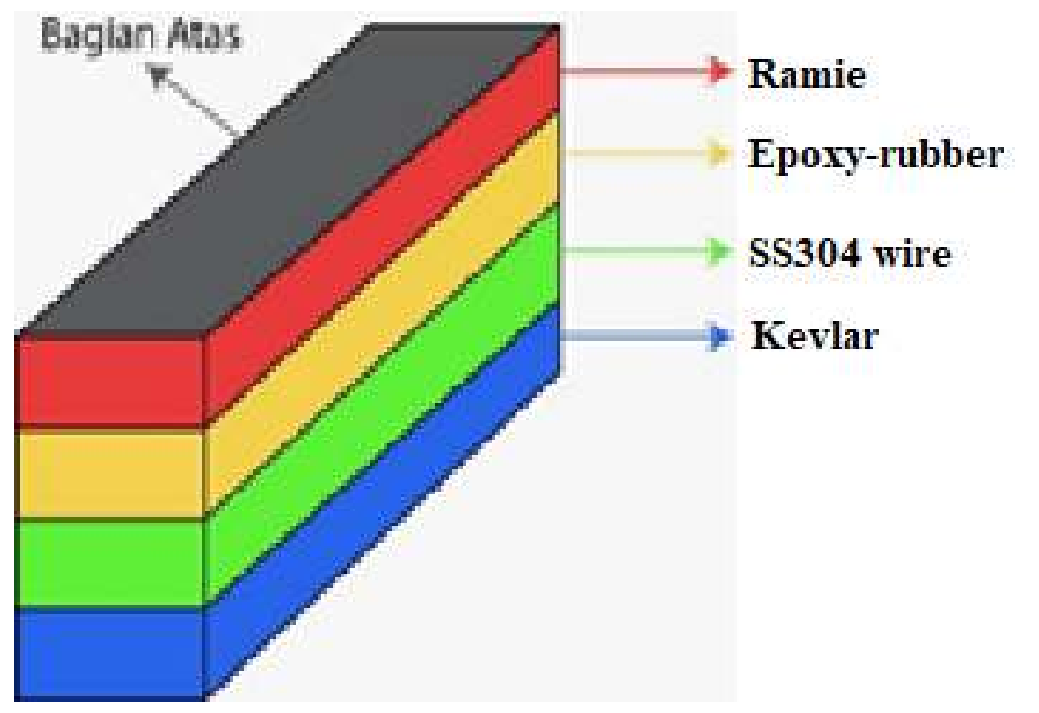

Fig. 3. Composite Specimen Lamination Schematic

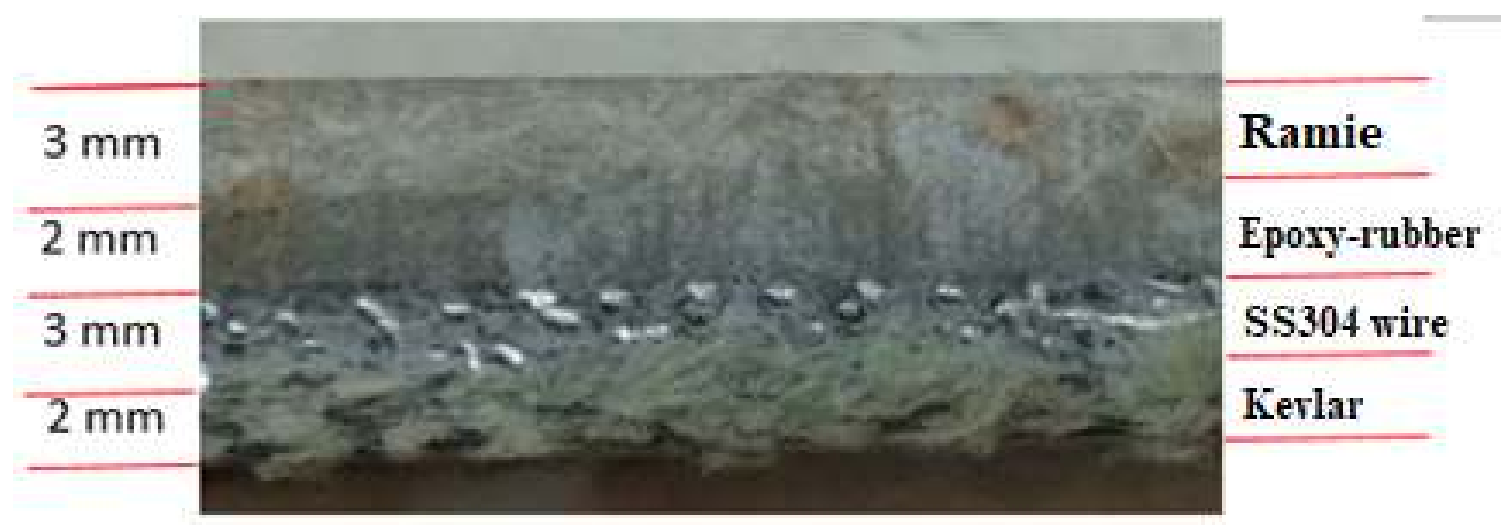

Fig. 4. Composite Specimen Lamination Results 
A. Widi, W. Sujana, T. Rahadjo, G. Pohan, T. Nani, F. Rahmadianto, L. D. Ekasari

\section{DiscuSSION}

Tensile test data processing results

TABLE I. PULl TEST RESUlt DATA

\begin{tabular}{|c|c|c|c|}
\hline Rubber & \multicolumn{3}{|c|}{ Additional variations of fiber reinforcement (Kevlar carbon fiber and } \\
\hline \multirow[t]{2}{*}{ Variation $\%$} & \multicolumn{3}{|c|}{ ramie fiber) } \\
\hline & Wire $(\mathrm{kgf} / \mathrm{mm} 2)$ & $\operatorname{Kenaf}(\mathrm{kgf} / \mathrm{mm} 2)$ & Cotton $(\mathrm{kgf} / \mathrm{mm} 2)$ \\
\hline \multirow{3}{*}{30} & 6.658 & 10.00 & 0,470833333 \\
\hline & 7.256 & 10.19 & 11.34 \\
\hline & 7.374 & 0,515277778 & 0,432638889 \\
\hline \multirow[t]{2}{*}{ Average } & 7.096 & 0,463194444 & 10.50 \\
\hline & 9.316 & 07.29 & 0,354861111 \\
\hline \multirow[t]{2}{*}{40} & 8.416 & 12.20 & 0,463194444 \\
\hline & 7.482 & 07.18 & 0,421527778 \\
\hline \multirow[t]{2}{*}{ Average } & 8.417 & 0,395138889 & 09.42 \\
\hline & 6.883 & 0,35625 & 0,464583333 \\
\hline \multirow[t]{2}{*}{50} & 6.629 & 0,440277778 & 11.07 \\
\hline & 6.746 & 0,384027778 & 08.14 \\
\hline Average & 6.752 & 0,393055556 & 0,442361111 \\
\hline
\end{tabular}

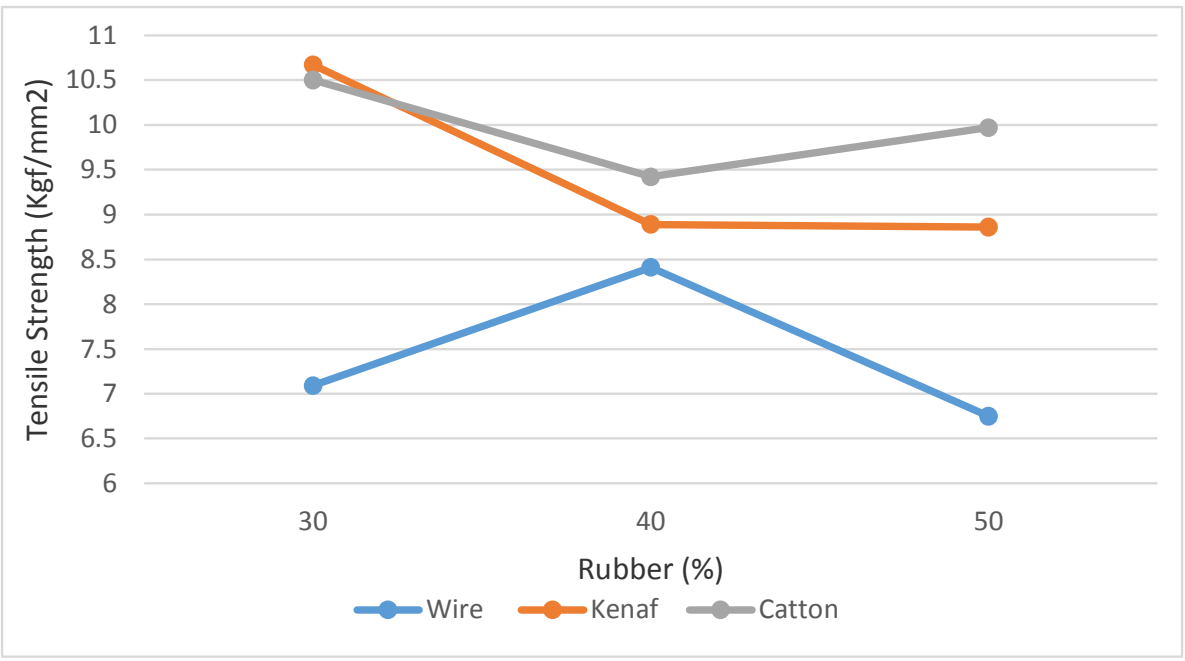

Fig. 5. Graph of tensile test result data 
TABLE II. FRACTURE OF TENSILE TEST RESULTS

Additional variations of fiber reinforcement (carbon fiber and ramie fiber) Joule $/ \mathrm{mm}^{2}$

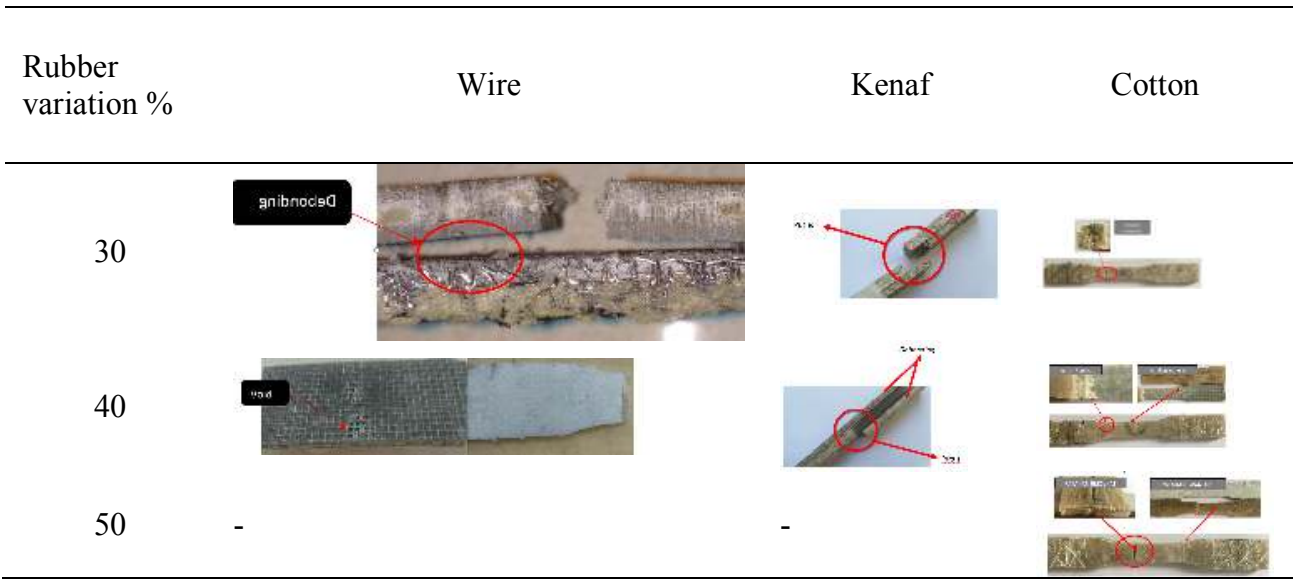

In Table 2, the addition of wire generally showed that the tensile strength of the composite decreased with the increased in the volume fraction of the white rubber in the matrix, while the strain (elongation) increased. This happened as during the tensile testing process, the material was partially broken [10]. Figure 6 of $40 \%$ rubber was a fracture in the tensile test specimen in the form of debonding. Debonding was the mechanism for the loosening of the interface bonds between the composite constituent materials when loading and peeling of the fibers or reinforcement from the matrix. This was due to the weak interfacial bonding between the fibers and the matrix. The bonding conditions between fibers and matrices were weak when given tensile loads, meaning that the bonds between fibers and matrices were easily released or experience debonding before they could completely distribute the load on the reinforcement and reduce overall composite performance [1]. Debonding defects could be seen in Table 2 which occurs in the interface bond between the reinforcing epoxy-rubber mixtures with SS304 woven wire. Figure 7 (B) showed the surface or interface between the woven wire and the epoxy-rubber mixture reinforcement. On the reinforcing surface of the epoxy-rubber mixture, it could be seen that the surface of the reinforcement did not have pores so that the matrix could not enter to bind the reinforcement.

In Table 2, the addition of Kenaf fibers with a percentage of $30 \%$ silicone rubber showed that the specimen had broken down as a whole. Hemp fiber and kenaf fiber did not break at the same position as the silicon rubber and Kevlar carbon fiber because there was no stress transfer between the hemp fiber and the kenaf fiber during the tensile test. In addition to differences in material strength, another reason that caused the specimens to not break at the same position was due to the coating method when making specimens using the lamination method in which this lamination method piles up all the reinforcing fibers and was separated according to each fiber type, lamination consists of a minimum two different layers linked together [3]. Meanwhile, 40 and 50\% rubber with kenaf fiber reinforcement showed that the specimen was not completely broken (only occurs in hemp and kenaf fibers). At the testing when the specimen was pulled, an imbalance of the pulling load occured due to the different strength of the constituent material and the bonds between the fibers and the matrix which was weak when given a tensile load. The bond between the matrix and the fibers will easily be detached or debonded, thereby reducing the overall performance of the composite. Debonding was caused by weak interfacial bonding between fibers and matrices [9].

In Table 2, the addition of cotton showed that the specimen with a mixture of $30 \%$ silicone rubber and epoxy was mixed fracture damage. This occured because the composition that was less rubber caused the material to be stiffer and the transfer of tensile stress to the test equipment could be properly carried out by the reinforcing fiber matrix until the fiber broke causing the high tensile value. Meanwhile, the occurrence of granular fractures in the cotton fiber fracture, fibrous fracture occurred in the carbon fiber and ramie fracture. The damage that occurred in specimens with a mixture of $40 \%$ silicone rubber and epoxy resulted in mixed fractures [7]. This was because the material was slightly softened by the increased silicone rubber mixture, which caused the matrix material in the specimen to be unable to transfer the tensile stress from the test equipment properly to the reinforcing fibers until the fibers did not break properly. This caused the pull value to decrease. Whereas the occurrence of granular fragments in the release of the bonds between the mixture of silicone rubber and hemp fibers was caused by shifts between the fiber layers while holding the tensile load so that between the fiber layers separated, fibrous fractures occured in the ramie fibers. The occurrence of granular fractures in the cotton fibers and the release of the bonds between the $50 \%$ rubber mixture and epoxy with hemp fibers were caused by shifts between fiber layers when holding tensile loads. Fibrous fractures occured in hemp fibers and the large number of silicone rubber mixtures made the bonds between fiber layers weaker; it was proven by the visible amount of silicone rubber in the granular fractions. 
A. Widi, W. Sujana, T. Rahadjo, G. Pohan, T. Nani, F. Rahmadianto, L. D. Ekasari Impact Test Data Processing

TABLE III. Data of Impact Test Result

\begin{tabular}{|c|c|c|c|}
\hline \multirow{2}{*}{$\begin{array}{l}\text { Rubber } \\
\text { Variation } \\
\%\end{array}$} & \multicolumn{2}{|c|}{$\begin{array}{l}\text { Additional Variety of Fiber } \\
\text { (Carbon and Ramie Fiber) }\end{array}$} & Reinforcement \\
\hline & $\begin{array}{l}\text { Wire } \\
\left(\text { Joule/mm }{ }^{2}\right)\end{array}$ & $\begin{array}{l}\text { Kenaf } \\
\left(\text { Joule } / \mathrm{mm}^{2}\right)\end{array}$ & $\begin{array}{l}\text { Cotton } \\
\left(\text { Joule } / \mathrm{mm}^{2}\right)\end{array}$ \\
\hline \multirow{3}{*}{30} & 0.035 & 0.031 & 0.031 \\
\hline & 0.034 & 0.031 & 0.029 \\
\hline & 0.034 & 0.031 & 0.033 \\
\hline \multirow[t]{2}{*}{ Average } & 0.034 & 0.031 & 0.031 \\
\hline & 0.035 & 0.029 & 0.031 \\
\hline \multirow[t]{2}{*}{40} & 0.038 & 0.031 & 0.029 \\
\hline & 0.038 & 0.031 & 0.029 \\
\hline \multirow[t]{2}{*}{ Average } & 0.037 & 0.030 & 0.030 \\
\hline & 0.040 & 0.027 & 0.029 \\
\hline \multirow[t]{2}{*}{50} & 0.038 & 0.029 & 0.029 \\
\hline & 0.040 & 0.029 & 0.027 \\
\hline Average & 0.039 & 0.028 & 0.028 \\
\hline
\end{tabular}

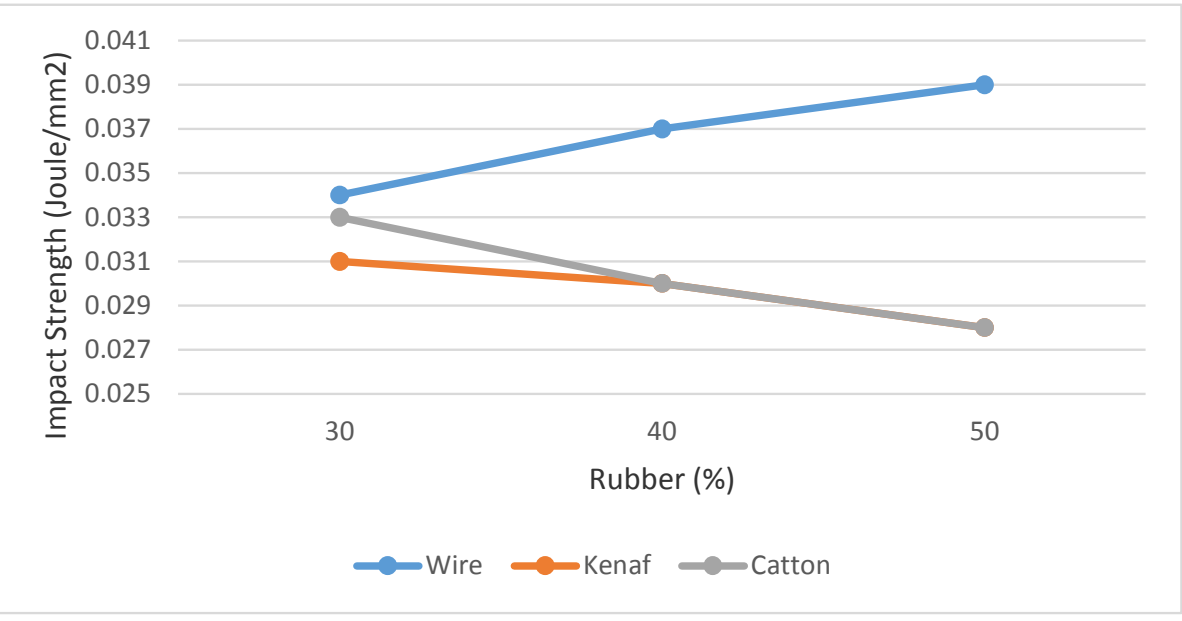

Fig. 6. Impact Test Data Graph 
TABLE IV. Fracture OF IMPACt TeSt SPECIMENS

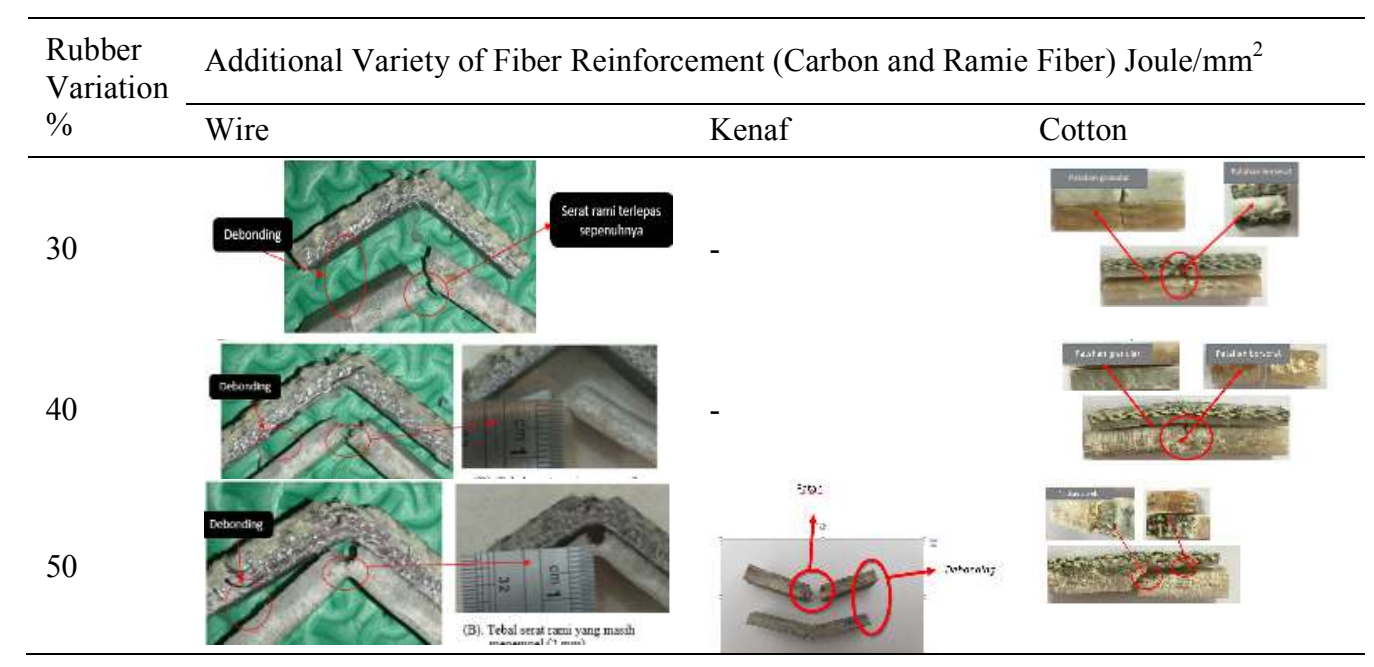

In Table III, the addition of wire in general showed that the greater the variation in the percentage of the addition of rubber to the epoxy-rubber mixture reinforcement, the greater the impact price obtained. The more white rubber volume fraction was added, the impact strength of the composite increased [12]. From the fracture image of the impact test specimens, it could be seen that all specimens on average experience debonding at the interface between the reinforcing epoxy-rubber mixtures with woven wire because SS304 wire was metal and had a smooth surface so that the epoxy matrix had low adhesion on the SS304 wire.

Low adhesion was also found at the interface between the reinforcement of the epoxy-rubber mixture with wire mesh because the reinforcing form of the epoxy-rubber mixture was in the form of a plate and there were no gaps for the entry of the epoxy resin matrix into the cracks of the epoxy-rubber mixture reinforcing plate. The adhesion was also influenced by the roughness of the material so that the rougher a material is, the higher the friction coefficient and the adhesion will also increase [2]. From the explanation of the fracture that occurs in each of the specimens above, it could be said that the debonding between the reinforcement resulting from the epoxy-rubber mixture with woven wire. This occured because the adhesion of the epoxy as a binder between the reinforcement of the epoxy-rubber mixture and wire mesh has low adhesion. Therefore, it is necessary to carry out further research on the adhesion of epoxy with the materials that form laminated composites.

In Table III, the addition of Kenaf fiber with a percentage of silicone rubber of $30 \%, 40 \%$ and $50 \%$ showed that after the impact test was carried out, the specimen experienced debonding between the silicone rubber and ramie fiber. The fault occurred only in the ramie fiber reinforcement and kenaf fiber reinforcement. In Figure 8 we can see that Kevlar carbon fiber and silicone rubber could bond well. This happened after the specimen was impact tested. The occurrence of debonding between silicone rubber and ramie fibers according to visual observations was because the silicone rubber was in the form of a plate and did not have pores. Therefore, the epoxy matrix which functions as a binder did not adhere well, in contrast to other reinforcements which were fibers that were knitted or joined together into one unit so that the matrix could blend well. It can be concluded that the debonding between silicone rubber and ramie fibers was due to the shape of the silicone rubber in the form of a plate and the absence of pores for the epoxy matrix to enter into the cracks of the silicone rubber reinforcing plate. Unlike the case with ramie and kenaf fibers which had pores or gaps in the entry of the epoxy resin matrix that made a good bond occured.

In Table III, the addition of cotton fibers showed the impact test results of fiber composite materials with $30 \%$, $40 \%$ and $50 \%$ silicon rubber mixed with epoxy with an epoxy matrix having the highest average impact strength in a mixture of $30 \%$ silicone rubber and the impact strength decreases. When the silicone rubber mixture was increased to $40 \%$, the impact strength decreased by 0.0015 joules $/ \mathrm{mm}^{2}$ and at $50 \%$ the impact strength decreases by 0.0031 joules $/ \mathrm{mm}^{2}$. This was because more and more silicone rubber mixtures in the composite material caused the material to become softer and the stress transfer by the impact force was not channeled properly from the matrix to each reinforcing fiber of the composite material. 


\section{CONCLUSION}

- The occurrence of debonding or detachment of the interface bond of the laminated composite due to the weak adhesion between the reinforcing epoxy-rubber mixture and the woven wire.

- The results of the addition of kenaf fiber specimens after the impact test were the same in all silicone rubber specimens of $30 \%, 40 \%$ and $50 \%$ experienced debonding between the silicone rubber and ramie fibers. Based on visual observations was due to the silicone rubber reinforcement in the form of plates and had no pores or gaps for the matrix entry. In the impact test specimens, only the ramie and kenaf fibers were broken, while the kevlar carbon fibers and the silicon rubber were bent.

- Macro photo results on specimens with cotton reinforcement showed that the damage due to tensile tests in the percentage of silicone rubber $30 \%$ was a mixed fracture. Meanwhile, in the percentage of $40 \%$ silicone rubber and $50 \%$, granular fracture only occured in ramie fibers and cotton fibers while in kevlar carbon fibers and silicone rubber there were no fracture.

- This study uses the hand lay-up method for making composites. If you find a better method, then do it to get maximum results.

- Further research is needed on the interface bonds between each reinforcements in laminated composites.

\section{REFERENCES}

[1] Hapsoro, D.S.2010. Pengaruh Kandungan Lem Kanji Terhadap Sifat Tarik Dan Densitas Komposit Koran Bekas. [Skripsi] Surakarta (ID) : Universitas Sebelas Maret.

[2] Hersyamsi.2005. Penggunaan Bahan Yang Mempunyai Nilai Adhesi Dan Koefisien Gesekan Dengan Tanah Yang Rendah Pada Landside Bajak Singkal Dalam Upaya Memperkecil Tahan Tarik [Disertasi] Bogor (ID) : Sekolah Pascasarjana Institut pertanian Bogor

[3] Irianpoo. 2016. Material Komposit. http://irianpoo.blogspot.com/2016/01/material-komposit.html diakses tanggal 23 Oktober 2019

[4] I Komang Astana Widi, Gerald Pohan, Wayan Sujana and Tutut Nani Prihatmi. 2019. Effect of Ramie Fibers on Fatique Strength Automotive Product. IOP Conference Series: Materials Science and Engineering, Volume 694, 1st International Symposium on Advances and Innovations in Mechanical Engineering 9-10 October, Jakarta, Indonesia

[5] I Komang Astana Widi, Wayan Sujana, Gerald Adityo Pohan, Putu Suwendra Saskara. 2020. Analisa Uji Tarik Dan Impak Komposit Epoxy Rami -Agave - Karbon dengan Campuran Epoxy-Karet Silikon (30\%, 40\%, 50\%), Jurnal Flywheel Vol. 11 No. 1 (2020): Jurnal Flywheel

[6] Joseph, Sadab Imam. 2018. Analysis of Hybrid Natural Fiber Composite Material by Using Finite Element Analysis, Materials Science, International Journal of Advance Research and Innovative Ideas in Education

[7] J. Thanikai Vimal, C. Prakash. 2018. Effect of Weave Parameters on the Tear Strength of Woven Fabrics, Journal of Natural Fibers, Vol 17

[8] Komang Astana Widi, Gerald Pohan, Wayan Sujana, Tutut Nani, and Luh Dina Ekasari, Comparative Investigation of Matrix and Fiber Orientation Composite Ramie. Lecture Notes in Mechanical Engineering, ISSN 2195-4356 ISSN 2195-4364 (electronic), ISBN 978-981-15-44804 ISBN 978-981-15-4481-1 (eBook), https://doi.org/10.1007/978-981-15-4481-1, Springer Nature Singapore Pte Ltd. 2020

[9] N.C.Huang, X.Y.Liu. Debonding and Fiber Pull-out in Reinforced Composites. Theoretical and Applied Fracture Mechanics Volume 21, Issue 3, November-December 1994, Pages 157-176, https://doi.org/10.1016/0167-8442(94)90031-0

[10] Pohan, Gerald A,Sugiarto, Totok, Arianto, Dwi Cahyo Galih, Utilization of Palm Fiber King as a Strengthening Material on Biocomposite, JOURNAL OF SCIENCE AND APPLIED ENGINEERING Vol 1, No 1 (2018): JSAE

[11] Sathivel, M., Vijayakumar, S. 2017. Influence of Stainless-Steel Wire Mesh on The Mechanical Behavior in A Glass-Fiber-Reinforced Epoxy Composit, 51 (3), 455-461. doi : 10.17222/mit.2016.063.

[12] Sujana, W. \& Astana Widi, I.K. 2013. Pemanfaatan Silicon Rubber Untuk Meningkatkan Ketanggihan Produk Otomotif Buatan Lokal. Jurnal Energi dan Manufaktur, 6 (1), 37-42

[13] Utomo.T, Rusnoto, Samyono.D, 2016. Analisa Sifat Mekanis Komposit Metrik Epoksi Diperkuat Serbuk Cangkang Telur Itik Untuk Roda Gigi Transportir Pada Mesin Bubut. Jurnal Teknik, 12 (6), 57-63

[14] Znanzhu. 2017. Standard Tensile Test ASTMD 638 Specimen Type I-V. http:/ www.thingivers.com/thing:2332080 diakses tanggal 19 Oktober 2019 